\title{
What's the Deal? Trump, Fichte's Closed Commercial State, and the Perverse Dialectic of Neoliberal Risk
}

\author{
Anthony Curtis Adler ${ }^{1}$ (I)
}

Received: 27 March 2020 / Accepted: 26 April 2020 / Published online: 8 May 2020

(c) Fudan University 2020

\begin{abstract}
The following paper seeks to understand Donald Trump as a "dialectical image" for the contradictions of neoliberal capitalism. Trump's management style, as described in his Art of the Deal, combines a fetishizing of entrepreneurial risk as a "lifestyle" with the insistence that it is not the entrepreneur but his targets who are ultimately exposed to risk. This suggests that we might understand the elevation of "deal-making" to a lifestyle as a characteristic of modernity that, with neoliberalism, is increasingly coming to the fore. Such a critique of modernity, I further argue, is anticipated by Fichte's Closed Commercial State with its intriguing dialectic of risk. I conclude by arguing that Trump's politics marks the rise of a new, specifically American style of Fascism-one that demands identification not with the state as supra-individual collective, but with an impersonal system governing over individual lives and rendering them precarious.
\end{abstract}

Keywords Donald Trump · US politics · Johann Gottlieb Fichte · Neoliberalism • Fascism $\cdot$ Economic nationalism

It's not that what is past casts its light on what is present, or what is present its light on the past; rather, image is that wherein what has been comes together in a flash with the now to form a constellation. In other words, image is dialectics at a standstill. For while the relation of the present to the past is a purely temporal, continuous one, the relation of what-has-been to the now is dialectical: is not progression but image, suddenly emergent.-Only dialectical images are genuine images (that is, not archaic); and the place where one encounters them is language.

Walter Benjamin, Arcades Project

Anthony Curtis Adler

anthony.adler@gmail.com

1 Underwood International College, Yonsei University, 50 Yonsei-ro, Seodaemun-gu,

Seoul 03722, Republic of Korea 
"Is there any difference between killing a man with a sword and with bad government?"

"There is no difference," was the king's reply.

Mencius

\section{Introduction}

The presidency of Donald Trump, whose hyperbolically self-promoting business style has made him an object of public fascination since the 1980s, has already given rise to a vast body of writing. In addition to the two biographies published prior to the 2016 election (Kranish and Fisher 2016; Johnston 2016), this ever growing literature includes not only several books published by mainstream trade presses (Wolff 2018; Johnston 2018) together with myriad newspaper articles and essays in public affairs magazines, but a growing body of academic literature dedicated to analyzing his psychology and personality type (Hearn 2017; Martin and Krause-Jensen 2017; Fuchsman 2017; Allcorn and Stein 2018), rhetorical style (Jamieson and Taussig 2017), political practice (Agnew and Shin 2017; Siegel 2017) and the relationship between his political and business career as well as to exploring his rise to power in light of broader trends in American as well as Global politics (Papalia 2017; Michels 2017; Massing 2018), transformations in the landscape of mass media (Andrejevic 2016; Wells et al. 2016; Werber 2017; Johnson 2018; Fürst and Oehmer 2018), and the dialectic of late capitalism (Hearn 2017).

The vast range of different analytic perspectives that can be cast on the phenomenon of Trump, most of which prove illuminating and nearly all of which register a feeling of trauma, suggests the extent to which this phenomenon itself not only represents a significant, perhaps ominous political event, but offers a singular illumination of the present situation. Indeed, if the phenomenon of Trump brings the present conjuncture into an unprecedented focus, it is precisely insofar as the situation of the present is not merely of the present, but issues from, and indeed carries over, the contradictions of the past-contradictions that are dialectical, in the sense of Walter Benjamin, insofar as they reveal an order of emergent temporality, of the time of the event as one might say, that is radically discontinuous with the continuous order of progress.

Indeed, the emergence of nearly every new celebrity phenomenon, when it is not just a matter of a new celebrity filling out an existing type but a new type of celebrity instantiated in an utterly singular individual, gives rise to a kind of uncanny feeling, especially among those who are not quite "with it"-who lag behind in becoming aware of popular culture. In a single moment, that which had appeared impossible, having no place in the world, not only suddenly seems inevitable and necessary, but draws everything else into its field of attraction, allowing other things to appear only in relation to it. A modal logician might, of course, still insist that there could be a possible world without Lady Gaga, Obama, or Trump: but this world, this absolutely singular world in which we exist-and we have never quite had the luxury of existing in another, merely possible world-has become utterly unthinkable without 
them, since the entire horizon of sense has come to be warped around the facts of their existence as if around a black hole.

With Trump, this feeling has not only assumed a vastly greater, and fundamentally traumatic, intensity, but is qualitatively distinct. This is in part because the seeming triviality of celebrity phenomena, and indeed of everything, however enormous its impact, which has been relegated to the sphere of private life (e.g., the personal computer, social networking), serves a function similar to that of the stage's proscenium: it creates the illusion of a safe distance (the distance, indeed, of illusion) in relation to what is in fact threateningly close. Many, such as Inglis (2010), have recognized that celebrity (as opposed to fame, renown) is characteristically modern, or indeed, as Rojek (2004) argues, ineluctably woven into the fabric of contemporary society. But perhaps the phenomenon of celebrity itself, together with all that is subsumed within its orbit, might be regarded not simply as a consequence of modernity, but as a "coping mechanism," a reaction formation, that, as such, has itself made it possible to survive the condition of modernity and postmodernity. It is a way of processing historical change itself, insofar as it has already reached a feverish and traumatic pitch of intensity, into safer, less threatening forms: a cutification of historical time, as it were. The continuum-breaking irruption of the new becomes novelty - an object of contemplative pleasure, enjoyment, intrigue, fascination.

With Trump's election, however, it is as if, in a single blow, the world of celebrity, which had already begun to rub up against the other world of the reality show, had suddenly become absolutely, immanently-dangerously-real. Since Trump was already a celebrity in the 1980s, and indeed, as a celebrity businessman, already straddled two worlds and unsettled the protecting veil of illusion (and it is instructive, in this way, to take note of the two domains over which he claims his tasteless mastery: television and architecture-intimately related and yet polar opposites), his ascent to politician, indeed to "leader of the free world," involves a second-order shock, a second-order event: it is as if the entire order bound up in the phenomenon of celebrity has become the only thing it never could have been before: real. The enormity of this event must be recognized for what it is. Whatever else happens, and it is perhaps still too soon to tell, this has already happened: the logic of celebrification, transforming the event into novelty-the "domestication" and "cutification" of historical time itself-having served as the principal shock absorber for the shocks of modernity, has, in a shocking and sudden fashion, failed. There is now only celebrity, or no celebrity. Celebrity has become a quantitative, rather than qualitative factor, as is made evident when one considers how the various ranking schemes organizing social media allow a hitherto impossible comparison between, say, a teenage girl in Topeka, Kansas live-feeding videos of her cat to her ten "followers"- or even the cat itself - and Lady Gaga with her millions of minions. Before we thought of celebrities as outliers, deviations from a human norm; now we think of even ourselves as failed celebrities. There are now only monsters, little and big; no one, and perhaps nothing — not even animals (one thinks of Cecil the Lion) - that are still able to exist at all if they exist outside the monstrations of media. And hence there is also no reality-authoritative, serious, secure-beyond the veil of celebrity, save perhaps in the most intimate, disgusting facets of daily life. It is in this way that we might make sense of the recent somewhat hyperbolic talk about "post-truth." It 
is not that correspondence truth has suddenly disappeared from the world, or even that the norms guiding most forms of praxis and discourse have been undermined. Rather, what has happened is this: previously, media interfaced with the real by way of a strata of authorities who, themselves media figures and celebrities, were nevertheless able to set up a protective barrier between the mediascape and the realscape by offering an authorized, authority-bearing opinion. Regardless what this opinion was, and whose interests (state, corporate, ideological) it represented, its demonstrative authoritativeness, buttressed by serious gazes and steady, stentorian tones, served to keep the two worlds apart: daytime TV might be dominated by all manner of triviality, silliness, melodrama, but, come evening, when the men have returned home from work and families are gathered back together, Walter Cronkite would remind everyone that, far away, a war was being fought, that their neighbors' sons were dying, that students were protesting, that the world was changing. The shocks of real history, this is to say, were tied back to the comforting continuity of authoritative knowledge, sound common sense, abiding ethical, political, juridical norms, whereas the novelty of the event-always already corresponding to nothing, the event is always already "post-truth"-was relegated to the sphere of the trivial and ephemeral. Now, however, this mediating function-called into question from both the top down and the bottom up, squeezed from all sides-has lost much of its efficacy: it is becoming increasingly clear that not only, as the prophets of postmodernity anticipated, is there no outside to the media, but that the qualitative texturing - the topographic distinctions-within the mediascape have been flattened out, such that they remain mere quantitative signifers of qualitative differences, akin to the markings on a topographic map.

The following paper does not claim to offer an exhaustive, definitive analysis of the phenomenon of Trump, but rather seeks to encounter the vertiginous movement of event-full history by bringing into focus Trump as a dialectical image for the contradictions of the present situation. Perhaps the most fundamental methodological principle of this investigation is the belief, grounded in the remarks of the previous paragraphs, that, in order to gain access to the dialectical torsion at work, it is necessary to start out by juxtaposing something seemingly trivial and ephemeral with that which brings the further-reaching historical horizon into view. Hence I will attempt to read Trump starting from what might seem like an unlikely constellation: on the one hand, his board games and, on the other, Fichte's highly philosophical political-economic treatise on the Closed Commercial State, a text which may be regarded as the founding document of economic nationalism insofar as it defends the necessity of restrictions on commerce, going far beyond the tactics of mercantilism, not in terms of the comparative advantages to be gained by one party over another, but in terms of what is absolutely necessary for the sovereign nation state to exist. Even though the "economic nationalism" of Trump and Bannon shares almost nothing concrete with Fichte's proposals, it does draw, at least at an ideological level, on principles that find very pure expression in Fichte's treatise. This is nowhere so clear than in Trump's infamous promise to "build a wall and make Mexico pay for it." This expresses the very essence of Fichtean closure-Fichte too believes he can make other countries pay-hollowed out into a purely rhetorical gesture. 
This is, needless to say, only one possible approach to the complex phenomenon that is Trump and Trumpism, and yet its seemingly willful arbitrariness is precisely what is methodologically demanded: only a chance point of departure can offer a point of access to that which relentlessly undermines all the resources of sound political, juridical, scientific reasoning.

\section{What's the Deal?}

Among so many other firsts, one suspects that Donald J. Trump, $45^{\text {th }}$ President of the USA, is not only the first head of state of a world power to have hosted his own reality show but can also claim the distinction of having not one, not two, but at least three board games consecrated to his name: "Donald Trump: The Game," "I'm Back and Your Fired," and the "Apprentice Board Game." Given that the first of these predates his reality TV show "The Apprentice" by 15 years, this suggests a certain telos driving the peculiar phenomenon that is Donald Trump-it could even seem as though, if the survival-format reality show had not existed, Trump would have had to invent it. ${ }^{1}$ The fulfillment of Donald Trump is to become the game-master, the dealer-the house. And yet this is perhaps not quite as simple as it might seem: the house is the structure, the system, the law. Those who play the game are submitted to contingency; they must compete with one another and are exposed to all the moods that go with the ups and downs of fortune. The house-the system, the structure-by contrast, like the divine beings of which the German poet Friedrich Hölderlin writes, feels nothing, experiences nothing. If it is possible to occupy the position of the house, it is only by becoming inhuman; incapable of human pleasure. Trump, however, seems to want it both ways: he wants to be the house, free of risk but also free of joy, and he wants to be a winner, the biggest winner. He wants to be both the dealer and the one who deals consummately with that which has been dealt.

Precisely this double desire is articulated throughout Trump's The Art of The Deal. From its first pages, Trump claims that his animating desire-the ultimate good orienting all his choices and actions-is neither wealth nor even (as one might suspect now more than ever, and which is certainly in fact the case) power:

I don't do it for the money. I've got enough, much more than I'll ever need. I do it to do it. Deals are my art form. Other people paint beautifully on canvas or write wonderful poetry. I like making deals, preferably big deals. That's how I get my kicks (Trump and Schwartz 1987).

\footnotetext{
1 Regarding the significance of Trump's career as reality TV host, see Ouellette (2016), Hearn (2016, 2017) and Kavka (2018). General studies of reality TV, and its transformative impact on American society, include Hill (2014) and Deery (2015), as well as the edited collection by Murray and Ouellette (2004). But perhaps the most profound and trenchant reflection on Reality TV, with regard to the 1971 show An American Family, appears in Baudrillard's Simulacra and Simulation: "Ideal heroine of the American way of life, it is, as in ancient sacrifices, chosen in order to be glorified and to die beneath the flames of the medium, a modern fatum. Because heavenly fire no longer falls on corrupted cities, it is the camera lens that, like a laser, comes to pierce living reality in order to put it to death" (1994).
} 
Deal-making is an end in itself. I do it to do it-which is to say, following Aristotle, "deal-making" belongs among the activities that can coherently be pursued for its own sake; that is not merely a means to an end, but an end in itself. It determines a form of life in the fullest sense. In the first book of the Nicomachean Ethics, Aristotle speaks of three ways of life that hold a special prominence, gathering together and illuminating our varied paths as human beings upon the face of the earth: the life of pleasure, the political life (the life of honor or of virtue), and the contemplative life. (Aristotle 2002) Each of these lives is oriented around a "good" that can coherently present itself as the meaningful, and meaning-giving, end of human action. By contrast: "the life of money making is a type of compulsory activity, and it is clear that wealth is not the good being sought, since it is instrumental and for the sake of something else." (Aristotle 2002) For Trump, it would seem, deal-making is a fourth kind of life.

It is worth taking a few moments to consider this claim, and indeed to take it seriously; far more seriously than it might at first seem to merit. If deal-making can be subsumed, as species to genus, under one of Aristotle's existing three lives, then Trump's claim that deal-making can be done just for the sake of doing it would not amount to much. Yet perhaps things are not so straightforward, and the deal-making life cannot be easily subsumed under Aristotle's rubrics.

Let us suppose, to begin with, that deal-making is merely part of the active life, the political life; the agora, the place of assembly in democratic Athens, was nothing else than a market place. If deal-making is a political activity, and even in the highest sense, then it is, nevertheless, of a peculiar, and peculiarly modern kindperhaps almost unrecognizable to Aristotle. It must be understood in terms of the modern reconception of politics in terms of a social contract-a social contract that is not merely foundational, but constantly being renegotiated, with political life the continual conflict between contracting parties.

But there is also another possibility: Aristotle does not include the life of the artist among the three prominent lives; he cannot imagine, as can we moderns, creativity and artistic production not only as something done for its own sake, but as a life that can claim a dignity and significance equal, or perhaps greater, than that of the politician or thinker. So we might say, rather, that the life of deal-making is a version of the creative life, made possible, as Hannah Arendt (1998) had argued in The Human Condition, by the post-Classical ascendance of homo faber. Or finally, drawing together these two points, we could even say that deal-making exemplifies the way in which political life is transformed through the rise of homo faber. Yet this conclusion does not seem quite adequate, either, since as Hannah Arendt argues, the modern world is characterized by the rise of homo laborans and the suppression of both the life of making as well as activity. We cannot then discount the possibility that deal-making belongs also, or perhaps principally, to the life of pleasure and even the life of contemplation.

If indeed deal-making is a kind of art, a kind of artistic life, it is characterized by a fastness and looseness, an openness to the moment.

Most people are surprised by the way I work. I play it very loose. I don't carry a briefcase. I try not to schedule too many meetings. I leave my door open. 
You can't be imaginative or entrepreneurial if you've got too much structure. I prefer to come to work each day and just see what develops... There's rarely a day with fewer than fifty calls, and often it runs to over a hundred. In between, at least a dozen meetings. The majority occur on the spur of the moment, and few of them last longer than 15 min (Trump and Schwartz 1987).

Whereas the artist, as conceived by Aristotle, brings forth the form, contemplated beforehand, by working upon the material, the deal-maker, a master improviser, makes it up as he goes along; open to what is given, playing with what is given, making the best of every situation. ${ }^{2-}$ Art has become play. If Aristotle's techne, as Heidegger (2002) argues, is a kind of epistēme , involving knowledge of the form that is brought forth into the presence in the act of making, then deal-making involves a peculiar knowledge, quite different from knowledge of forms (of the generic, universal, eternal). The deal-maker gains knowledge of the situation. The essence of the situation is the conflict, the polemos, that plays out with every decision; that gets played out in every deal. In the words of Heraclitus's famous fragment:

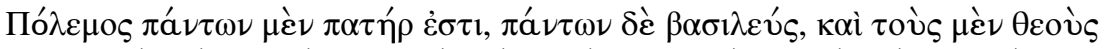

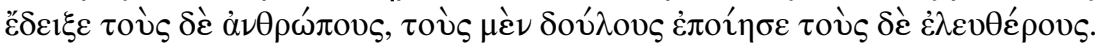

War is father of all and king of all; and some he has shown as gods, others men; some he has made slaves, others free (Heraclitus 1979)

Translated into Trump: "the deal is the leader; it shows the winners and the losers." The deal-maker is the one who to the greatest degree possible experiences the deal; who partakes of the pleasure of deal-making, of living as close to the center of the deal as possible. Perhaps, then, if deal-making constitutes an autonomous, self-sufficient, prominent mode of life, it is because it gathers together all the other possibilities of life (politics and activity more generally, artistic creation, knowledge and contemplation, and pleasure) into a single mode of life that is, or at least seems to be, capable of managing, dealing with, the modern condition. The deal-maker claims at once to master the fluidity of modern life and to submit pleasurably to this fluidity, to experience it as pleasure.

If the first chapter of The Art of the Deal marches us through a week of vertiginous deal-making, the second chapter, titled "Trump Cards," as if bringing a bit of order to the chaos, will describe the elements of the deal. It is not clear that deal-making can be taught: "More than anything else, I think deal-making is an ability you're born with. It's in the genes." Still, deal-making is not gambling; the deal-maker confronts the contingency of the moment, but he does not submit to chance.

\footnotetext{
2 Trump's "improvisatory" style, often remarked upon by political commentators, has already drawn the attention of scholars, including Jamieson and Taussig (2017), who draw attention to his "seeming spontaneity" as a key dimension of his "rhetorical signature." Rather little attention, however, has been paid to thinking about the meaning of improvisation itself, which, far from self-evident or unproblematic, is a tricky, subtle, and complex phenomenon, and one which, moreover, seems to have a particular resonance in contemporary life. The true significance of improvisation appears in a clearer light when we consider the close yet complex affinity between improvisation and comedy, which in turn implies a connection between non-improvisation (traditional authorial composition) and tragedy.
} 
People think I'm a gambler. I've never gambled in my life. To me, a gambler is someone who plays slot machines. I prefer to own slot machines. It's a very good business being the house.

It's been said that I believe in the power of positive thinking. In fact, I believe in the power of negative thinking. I happen to be very conservative in business. I always go into the deal anticipating the worst. If you plan for the worst-if you can live with the worst - the good will always take care of itself (Trump and Schwartz 1987).

The deal-maker at once submits to the deal, experiencing its vertiginous play, and yet indemnifies himself against all risk. By imagining, and even living with, what, under the given circumstances, would be the worst deal, the deal-maker is able to elevate himself beyond true risk. But of course ultimately the worst deal, the ultimate trump card, is death itself. The only way to indemnify the deal-maker against even this risk is to live only for the sake of the pleasure of the moment. Closing the chapter, Trump writes:

I don't kid myself. Life is very fragile, and success doesn't change that. If anything, success makes it more fragile. Anything can change, without warning, and that's why I try not to take any of what's happened seriously... The real excitement is playing the game... If you ask me exactly what the deals I'm about to describe all add up to in the end, I'm not sure I have a very good answer. Except that I've had a very good time making them (Trump and Schwartz 1987).

Here, the paradoxical nature of deal-making as a form of life, a manner of living, reveals itself most fully. The deal-master tries to experience the deal and master the deal at one and the same time. He tries to master the deal by forethought, anticipation of risk, and yet the greatest degree of forethought brings us before a risk, a fragility to things, that cannot be surmounted. So it would seem the deal-maker must live for the present; the life of the deal is not a life of art, of creativity, but a life of pleasure. The temporal horizon of the deal-maker collapses into the present. And yet it is also not clear if the deal-maker can ever actually experience the pleasure of the moment. "It never stops, and I wouldn't have it any other way. I try to learn from the past, but I plan for the future by focusing exclusively on the present. That's where the fun is. And if it can't be fun, what's the point." (Trump and Schwartz 1987) One can only live in the moment, but the moment only exists in the future. Ultimately, fun is had only in the past: the life of deal-making lives fully in a present that only ever exists in the future, and only ever knows that it has lived at all by looking back at all the fun it has had. Fun, in fact, is not something we feel, something we enjoy, but something that is made, bought, had: the commodity form of pleasure. 


\section{Deal-Making as the Pathology of Modernity}

In the last pages, I have tried to show that Trump's deal-maker, his deal-making as a way of life, exemplifies the paradoxical temporality of life under late capitalism. One might speak, in this way, of a psychopathology of everyday life, though perhaps in a sense that owes as much to Heidegger as to Freud. What is most interesting about this account is that it shows the pathology from the side of the winner, the absolute winner. Usually, capitalist pathologies start from the side of the "losers"; failed salesmen, drug addicts, compulsive gamblers, neurotics of all shapes and stripes. ${ }^{3}$ Now, it is possible to see that the pathology of the loser is merely a special case, and limiting case, of the pathology of the winner. Yet what interests me above all is the way in which this pathology already manifests itself in Fichte's thought—and not simply as a private quirk, an idiosyncrasy, but as the constitutive horizon of German idealism, and even of modern philosophy as such; a horizon that continues to play itself out not only in Hegel, Schopenhauer, and Nietzsche, but even in Heidegger... This is not meant as a critique ad hominem; it speaks to the greatness of a thinker to bring forth the ruling characteristics of the age, even if this is itself pathological.

A more far-reaching version of this argument could be sketched out as follows: whereas for Aristotle luck and chance mark the limit to causal explanation and hence to the rational articulation of what is (things can be said to happen by chance, yet chance is not a cause in its own right), modern philosophy (as is clear in empiricism) will begin to regard contingency as a primary and positive source of knowledge. The tension between necessity and contingency, as also between autonomy and heteronomy, comes to the fore. German idealism regards this tension as generative, productive, and ultimately seeks a systematic reconciliation. Heidegger, in turn, following Schelling and Nietzsche and also Hölderlin, returns to this tension but makes it irreducible, fundamental, starting with his "existential" analysis of thrownness and projection. The most recent philosophical encomiums to "radical contingency" must themselves be seen in this light

The current paper will restrict itself to addressing only one piece of this puzzle, though, indeed, a very important piece. For indeed Fichte recognized, with greater clarity than most if not all of his contemporaries, that the experience of life as a "game of chance" is the constitutive horizon of the present age. Yet at the same time he rejected both the Hegelian conviction (which even certain forms of Marxism would continue to hold on to) that this game is stacked in the direction of progress, as well as Schelling's belief that a purely ideological mastery of the game would suffice. For Fichte, by contrast, the gaming quality of modern life demanded one last gamble that could only play itself out on the world-historical stage; an

\footnotetext{
3 The tendency of the left to paint Trump as a loser rather than a winner not only misses the point but is dangerously naïve; one might even say that the comic treatment of Trump, like Aristophanes' takedown of Socrates, fails to recognize the sense in which it is the pathologies of success rather than failure that characterize the tragic limits of the age. It took more than two millennia before Nietzsche could put Socrates at the center of a tragedy; namely the decline of tragic drama itself.
} 
extraordinarily risky "play" that will bring the game to an end. The only way to master the game is to finish it.

\section{Fichte's Closed Commercial State}

In the eighth and final section of the third and final book of the Closed Commercial State, Fichte, having presented what he regards as an absolutely compelling case for a proposal that, if carried through, would bring the ills of the world to an end, turns in anticipation to the question that must necessarily come to preoccupy all those whose philanthropic measures are rejected and mocked by the very ones they most wish to help: why won't they just do what I say? ${ }^{4}$ After observing the incapacity of the "great part of mankind" to follow out an argument presented as a series of deductions from first principles, he proceeds to set forth the true reason why the ideas he has proposed are "most profoundly displeasing to so many, who cannot bear to think of the state of things at which they aim."

It is a characteristic feature of our age, standing in sharp relief to the seriousness and sobriety of our ancestors, to wish to play and madly swarm to and fro with its fantasy, and since there are few other means available to satisfy this play-urge, it has a strong inclination to turn life into a game (Fichte 2013).

For Fichte, this tendency is not itself something blameworthy, but rather "a necessary step, induced through nature alone, on the path that leads our species forward," suggesting that while, like Schiller's Speiltrieb, it is rooted in something innate, its manifestation has a decisively historical character. Nor, moreover, is its primary manifestation aesthetic or even intellectual. Rather, the primary expression of this tendency, where its effects prove most pernicious, is in the sphere of economics:

As a consequence of this tendency, one never wishes to obtain anything by following a rule, but instead to have everything through cunning ruses and luck. Acquisition and all human commerce should resemble a game of chance. One could allow these men to have, keeping to the straight and narrow, the very things they hope to gain through intrigues, cheating, and chance, save on the condition that they now be content with it for the rest of their lives. They would then not want it. It delights them more to strive for things cunningly than to possess them securely. It is these people who incessantly call out for freedom - freedom of trade and acquisition, freedom from supervision and policing, freedom from all order and morality. Whatever aims at strict regularity and at things taking a firmly ordered, thoroughly uniform course will appear to them as an infringement on their natural freedom. Such people must be repelled at the very thought of an arrangement of public commerce in

\footnotetext{
4 The last decade has seen a resurgence of interest in Fichte's Closed Commercial State, including Isaak Nakhimovsky (2011), Adler (2012), and Tyler (2015).
} 
which swindling speculation, accidental profits, and sudden wealth would no longer occur (Fichte 2013).

This tendency, Fichte goes on to claim, gives rise to a frivolity more concerned with present enjoyment than future security, and whose "life wisdom for individuals, and its politics for states, consists only in the art of getting out of the present jam, with no care given to the future difficulties that one is thrust into through the remedy that was taken. For such frivolity the security of the future, which one promises to it and which it never itself desires, is no valid substitute for the unbridled freedom of the moment that alone entices it" (Fichte 2013).

It is hard not to appreciate the prescience and force of Fichte's diagnosis, and not least of all since it would seem as though, even if the emergence of a complex apparatus of regulative structures and the welfare state might give the appearance of progress, these measures appear in the end not only as reactive and insufficient, but have proven incapable of resisting the triumphant march of neoliberalism, which, especially in the shape given to it by Hayek and the Chicago School, has turned the anarchic power of chance, now elevated and scientifically legitimated as a power of spontaneous self-organization, into the ultimate principle of things. Precisely because Fichte regards the fundamental tendency of his age not as one countervailing factor among others in a progressively unfolding historical dialectic, but as an extreme horizon in which the very possibility of any sort of goal-directed action is called into question, he must reject the view of the political, given brilliant expression two decades later with Hegel's Elements of the Philosophy of Right, as the reconciliation of the freedom and particularity of the individual with the abstract universality of the state.

Thus, the Closed Commercial State itself proposes a social arrangement in which the economic existence of every individual is completely regulated by the state, which grants to each individual not only the right to pursue a certain defined economic activity (extracting produce from this piece of land, pursuing this specific trade) but guarantees that, in return for their labor, they will be able to provide themselves with the necessities of life. Citizens will be forbidden from freely engaging in economic activity with foreign entities, and indeed travel abroad will only be permitted to scholars and artists. Even though this vision of the state might seem perversely anti-modern, Fichte indeed regards it as the culmination of the historical process of modernity: the emergence of the sovereign nation state reveals a tendency toward closure, and yet the merely juridical closure of the Westphalian state is not enough, and must be supplemented by complete economic closure. In a powerful and prescient analysis of the global order of colonial relations, Fichte argues that these are not only fundamentally exploitative, but that they must ultimately lead to the complete destitution of weak nations, which, as a result of trade imbalances, will ultimately be compelled to sell their own sovereignty to the highest bidder.

The Closed Commercial State consists in three books: the first offers a rational deduction of the ideal arrangement of economic relations, culminating in a theory of property as the exclusive right to a certain kind of activity. The second concerns the "history of the present," arguing, in effect that Europe originally constituted a single vast system of trade, and yet was in the process of dividing itself off into 
nation states. Here, he claims that mercantilism itself represented a series of halfmeasures undertaken in pursuit of economic closure. If one were to consider the passage cited above with a view only to the argument pursued in the first two books, Fichte's reasoning would seem peculiar if not altogether bizarre. On the one hand: there would seem little or no point in offering a proposal that is so contrary to the spirit of the age and its tendencies. On the other hand: if the tendency of the present age is toward closure, then this would not only suggest that the present age is more serious than might first seem to be the case, but that indeed the relation of the playful and the serious, as modes of existence, is more complex than Fichte's closing words suggests. Or perhaps indeed, if playfulness is itself a necessary step driving the species forward, then this might imply that the playful wheeling and dealing man of the present is in fact the agent of world history's very serious intentions, whereas Fichte's economic philosophy, in all its ponderous heavy Teutonic seriousness, is a non-starter. Such considerations, it would seem, must lead us to the path taken by Hegel who, moreover, saw with great clarity the totalitarian tendencies of Fichte's seemingly consequent liberalism.

The third book of the Closed Commercial State, however, moves in an altogether different direction. Here, Fichte proposes nothing less than a kind of trick for catalyzing a chain of commercial closures. This trick, introduced under the title of "politics," goes as follows: one of the dominant economic powers in the world will suddenly carry out a "money operation" that involves replacing all the gold currency used within its borders with a national currency, made of a material that is at once cheap and yet impossible for private parties to counterfeit, whose value is fixed, and whose validity is guaranteed, by the state. The first state that does this will reap tremendous benefits, instantly nearly doubling its wealth, since its gold will be freed up from its function as a domestic means of exchange. It will be able to acquire tremendous military power, which it can and must use for the sole purpose of claiming the natural boundaries needed for a self-sufficient economic existence. Other states, seeing this, will follow, though they will benefit less than the first. Eventually, all states will be compelled to close themselves off economically just to survive.

It can hardly escape us that Fichte's "money operation" consists in an enormous (and seemingly mad) geo-politico-economic wager. If the first country to close itself off can reap the greatest benefits, it is only because it has exposed itself to the greatest risk. I do not think it could have escaped Fichte that the "money operation" might have instantly led to an immediate and disastrous political crisis. Fichte does not spend much time on these risks, but this is not because he does not take them seriously, but rather because he is concerned above all with "selling" his proposal to those who are in a position of power. He, we might say, is convinced that the danger that the present world faces is so great that only this sort of gamble could lead us back from the abyss. What he fears most of all is that the very economic conditions which allow for a noble, free, truly human existence will be destroyed. In the best tradition of the philosophers, he is afraid for philosophy, for the dignity of contemplative human reason. And yet it is precisely the characteristic of the present age, its love of risk and gambles and tricks and cunning, that makes Fichte's world-historical wager possible. Only a world that loves to gamble could find a statesman crazy enough to gamble everything. But what is the payoff: peace on earth-among states 
and within each state's own territory. An abrupt end to the dynamism of history; the substitution of the madness of history with a gentle, stable progress based on the peaceful, but very limited interactions of nation states, each with its own welldefined, rich national character.

Once this system has become universal and eternal peace is established among the different peoples, there is not a single state on the face of the earth that will have the slightest interest in keeping its discoveries from any other, since each will only use these for its own needs inside its boundaries, and not to oppress other states and provide itself with superiority over them. Nothing, it follows, will prevent the scholars and artists of all nations from entering into the freest commerce with one another. The public papers will no longer contain stories of wars and battles, peace treaties or alliances, for all these things will have vanished from the world. They will only contain news of the advances of science, of new discoveries, of progress in legislation and the police, and each state will hasten to make itself home to the inventions of other (Fichte 2013).

Almost two centuries before Francis Fukayama, and more than a 100 years before Kojeve, Fichte envisions the end of history. And yet the end of history will not be brought forth more or less of its own accord through the ruse of history, driving forward through suffering and contradiction toward the absolute, but through the ruse of Fichte. Perhaps, had Fichte not existed, another great thinker would have figured out the "money operation"-yet whoever discovers it, and however long this takes, it will always involve an event that intervenes in the existing order of things, catalyzing a chain reaction of occurrences that will leave the world utterly transformed. ${ }^{5}$ This event is not destined or necessitated in any way; it is an intervention and an invention: a fundamentally new kind of currency, imposed from the top down, introducing a new kind of numismatic regime, a new sovereignty beyond all sovereignty. ${ }^{6}$

For Fichte, true property must issue in free activity. He indeed believes that the fundamental error of all existing theories of property consists in the fact that "one posits the first, original property in the exclusive possession of a thing." Against this, his theory maintains that "the first and original property, the basis of all others, [consists] in an exclusive right to a determinate free activity." (Fichte 2013) But if we take this Idealistic theory of property, already developed with great consequence, seriously, then we might ask: how is it that the human race appropriates its own history, such that it can become most fully the property of itself in its historical existence — or such that, indeed, its historical existence could be the very event of self-appropriation. This is a vital question, a necessary question, since

\footnotetext{
5 It is from this perspective, moreover, that one can begin to appreciate the significance of the invention of the blockchain structure used in cryptocurrencies such as Bitcoin. Its dissemination is a truly Fichtean counter-Fichtean gesture: a challenge to the very structure of state sovereignty that Fichte seeks, above all else, to uphold.

${ }^{6}$ Perhaps Fichte's most interesting and radical insight consists in the claim that the very existence of money as a means of exchange, so long as its value is established by a kind of global opinion, compromises the possibility of the integral and self-sufficient nation state. The sovereign power of gold undermines the pretense of national sovereignty.
} 
without this historical self-appropriation human freedom would amount to nothing. The thought of the early "humanistic" Marx still operates within the horizon of this question, and it is perhaps still even at work in Heidegger's Ereignis- the propriative event. Here, however, the difference between Fichte and Hegel comes into striking view. For Hegel: history is the ongoing process by which absolute spirit appropriates itself, passing from dunamis to energeia. It is in just this sense, indeed, that Hegel could have never actually entertained an "end to history" in any simple sense. For Fichte, by contrast: the highest appropriative event is the wager of the philosopher-statesman; the wager to end all wagers, and hence end a history that has been characterized by chance. There is in this way a kind of Platonism at work in Fichte: the philosopher is the one who, owing nothing to the world in which he was born, precipitates an event of conversion; the first in the chain of liberating actions. Human beings can only take ownership of their historical existence, hence of their humanity, by acting in a decisive way against the riskiness in which their existence is enmeshed. And yet such a decision, which need in fact only happen once and can originate with one visionary, is itself risky to the highest degree. It is only possible as the highest wager. The secret motto of Fichte's Closed Commercial State is, one could almost say, the Hōlderlinian bon mot, coined 2 years later, that Heidegger, writing in the wake of the devastation of the Second World War, draws on in The Question Concerning Technology: "Wo aber Gefahr ist, wächst das Rettende auch"- where the danger is, there too is salvation, the saving power.

Yet this must give us pause: Fichte offers a powerful and prescient critique of the form of life that, now more than ever, has come to prevail under the conditions of capitalism. But he also succumbs to the conceit that it would be possible to play the game and master the game at the same time, to expose oneself to risk while indemnifying oneself against risk. One might claim that risk-taking has no essential value for Fichte: I do not think this is so, however. Speculative thought is risk-taking thought; the speculative desire of the philosopher is of a piece with the characteristic of the age. Indeed, Fichte recognizes as much when, claiming that many wrongly blame poetry and philosophy for the frivolousness of the age, he remarks that poetry and philosophy are not responsible for this phenomenon, but merely serve, in the case of the former, "to divert [it] toward something else than life," and, in the case of the latter, to challenge "it to the extent that it concerns itself with life." This can only mean that, in its proper domain-beyond the sphere of ordinary life-philosophy remains playful.

Precisely this is the bad faith - the pathology — of capitalism as a form of life, which, moreover, assumes ever more complex and concrete forms with the emergence of new and ever more intricate ways of monetizing risk. Capitalism fetishizes risk, and yet, the more that precariousness becomes the general condition, the more that capitalists are able to profit from a risk in which they no longer has to partake. The paradox of this pathology, however, is as follows: the more relentlessly the "losers" at the game of life find themselves exposed to this precariousness, the more they struggle to find a perspective for their own lives according to which they can become masters of the risk to which they are exposed. Contemporary forms of life are characterized by this dualism, which itself functions as ideology regardless the particular forms it assumes. 
Let us consider, once more, Donald Trump's reality show, "The Apprentice." This genre of reality show should be thought of as a perverted Brechtian drama. Brecht's plays sought to present the human condition, with its relentless struggle for survival, in such a way that we could realize that this is not a fateful tragic condition to which we are condemned, but a historical reality that we have created for ourselves. The reality show turns this on its head: the struggle for survival appears, on the one hand, as purely the effect of the artificial contrivances of the show, which has forced people together into a confined space to compete in contrived challenges, and yet at the same time elevates this very artifice to a law of fate. It says, in effect: we must struggle against each other because the celebrity game-master tells us we must do so. We must submit to the celebrity game-master because everyone who is not a celebrity, everybody who is a nobody on the way to becoming somebody, must want to be a celebrity. Yet watching the reality show grants a pleasure that is denied to the participants; they are perhaps on the way to becoming celebrities, they have even been granted a little piece of celebrity, but they cannot identify with the game-master. We, however, who are watching, we who are not even participants in the game, we who are bigger losers than the biggest loser, can nevertheless identify completely with the celebrity game-master passing judgment on the winners and losers. "You're fired"-I knew it, we think to ourselves; that apprentice did such a bad job. She deserved to lose. Now they'll know who'se the boss!

\section{Economic Nationalism}

If there is a uniquely American style of fascism now in the offing, it consists at heart in this logic of identification. It is a fascism, in other words, that no longer depends on the suppression of the individual in the name of communitarian or collective values - values which, however, cynical their deployment by the propagandists of the ruling elite, nevertheless retain strong rhetorical force among the multitude. Donald Trump, at once master of the game and master-player, offers the perfect point for a new mode of identification, in which we identify ourselves not with the state, the collective, by sacrificing our claim to individual autonomy and rights, but rather identify ourselves, in our atomized individuality, with the system that governs our lives, dispenses with our lives, without either demanding sacrifice or offering the hope of rediscovering our individuality in the universal. We take pleasure in the system, live vicariously through the system, even though this itself inevitably condemns us, however much fun we have along the way, to lose. ${ }^{7}$

\footnotetext{
7 The "system" in this sense is not a universal in which the individual can recognize itself, finding itself affirmed and repeated at a higher level, if only through sacrifice. Rather, the system leaves the individual entirely to itself; like the gambler at the slot machine, the individual is left to pursue its own pleasures. Yet nevertheless all the individual pursuits constituting individual life can only happen in and through the system, which constitutes the horizon of meaningfulness and action without offering the prospect of an experience of a meaning that is either common to all or transcendental. The system thus becomes identifiable only by achieving a double existence: house and player at once.
} 
It is in this sense that we can understand Trump's economic nationalism. On the one hand, it is the very opposite of Fichte's; it has nothing to do with securing economic rights and economic justice through even a limited recognition of the responsibility of the state to provide its citizens with the possibility of a livelihood sufficient to allow for a dignified, fully human life. It has nothing to do, even, as some in the alt-right might have it, with the "cultural" integrity of the nation state. Rather: Trump's economic nationalism follows from the elevation of the president to the "deal-maker-in-chief"; economic relations between nations, this is to say, are mere occasions for the leader to show off his deal-making prowess, and this, in turn, serves to allow for popular identification with the one who is able to play the game, enjoy the game, and master it at the same time; who can keep on playing the game and yet can never lose.

In the case of Trump, of course, this identification itself only happens through various exclusions: of the racial and ethnic and sexual, of foreigners, of "liberals," of women who refuse objectification, and now of the elderly, the urban poor, and those with "preexisting conditions," all of whose lives, in the wake of the COVID-19 pandemic, have become expendable in the rush to "reopen" the economy. While it is this aspect of Trump's political style that has provoked the greatest degree of public outrage, it also suggests a point of vulnerability in the logic of late capitalism. For what it reveals, above all, is that it is still largely impossible to identify with the system, to take pleasure in the system, without these gestures of exclusion. It might be tempting to claim that this is because the logic of exclusion is itself structurally necessary to the system. Yet while it may well be the case that capitalism at once depends on and gives rise to stratifications that fall outside the strict logic of class conflict, the tendency of capitalism remains directed at the dissolution (at least at the level of the explicit, public ideology) of all "qualitative" distinctions, since these will inevitably stand in the way of the maximization of profit. What Trump has made clear, in a particularly brutal fashion, is that, while it is increasingly necessary to identify with the system, since all other forms of life have become hollowed out and can no longer offer a path to enjoyment and happiness, it is also, at least for a broad section of the population, impossible to identify with the system in its outermost purity and abstraction. To become "relatable," to become "livable," the system must again become precisely what it no longer is: a nation, an ethnicity, a race. Thus, in the eyes of many, the system has become divided into two systems, one good, one evil: the radically impersonal system of capitalism itself impersonated in the ethno-racial state and ultimately in the felicitous and happy image of the businessowner-Trump himself is a small businessman grown to monstrous proportions-and the radically impersonal system of the deep state, impersonated in the scheming agent, the journalist, the cultural-Marxist Jew. The need for this impersonation, and the surge of explicitly exclusionary idioms back into mainstream national politics, itself results from the failure of the project of division and identification that, since the end of the Second World War, conservatism in the United States and England has pursued: of the good system of life-affirming, creative entrepreneurial capitalism versus the bad system of totalitarianism and government regulation. Yet the complete failure of Trump to do anything, beyond adventuresome 
grandstanding in the global arena, to challenge the unfettered dominion of corporate interests suggests that the ethno-racial and nationalist impersonation of capitalism is just a mask for neoliberalism, which remains in force.

This circumstance is dangerous to the highest degree, but it also discloses an internal, structural contradiction within late capitalism that may well also offer a certain hope. It reveals the ultimate incapacity of capitalism to reproduce the ideological conditions of its survival.

Funding Not applicable.

\section{Compliance with Ethical Standards}

Conflict of interest The authors declare that they have no conflict of interest.

\section{References}

Adler, Anthony Curtis. 2012. Interpretative Essay: Fichte's Monetary History. In Johann Gottlieb Fichte, The Closed Commercial State, 1-71. Albany: SUNY Press.

Agnew, John, and Michael Shin. 2017. Spatializing Populism: Taking Politics to the People in Italy. Annals of the American Association of Geographers 107(4): 915-933.

Allcorn, Seth, and Howard Stein. 2018. Empty Vessel and Sum of All Projections. The Journal of Psychohistory 46(1): 2-16.

Andrejevic, Mark. 2016. The Jouissance of Trump. Television \& New Media 17(7): 651-655.

Arendt, Hannah. 1998. The Human Condition, 2nd ed. Chicago: University of Chicago Press.

Aristotle. 2002. Nicomachean Ethics (trans: Sachs, J.). Newburyport MA: Focus Publishing.

Deery, June. 2015. Reality TV. Hoboken NJ: Wiley.

Fichte, Johann Gottlieb. 2013. The Closed Commercial State (trans: Adler, A. C.). Albany: SUNY Press.

Fuchsman, Ken. 2017. The Presidential Campaign That Astounded the World: A Psychohistory of Donald Trump and the 2016 American Election. The Journal of Psychohistory 44(4): 292.

Fürst, Silke, and Franziska Oehmer. 2018. 'Twitter-Armies', 'Earned Media' und 'Big Crowds' im USWahlkampf 2016: Zur wachsenden Bedeutung des Nachrichtenfaktors Öffentlichkeitsresonanz. In Strategische Politische Kommunikation im digitalen Wandel, 35-61. Wiesbaden: Springer.

Hearn, Alison. 2017. Confidence Man. Soundings 66: 79-89.

Hearn, Alison. 2016. Trump's "Reality" Hustle. Television \& New Media 17(7): 656-659.

Heidegger, Martin. 2002. Die Frage nach der Technik (1953). In Gesamtausgabe: VII (Vorträge und Aufsätze), 5-36. Frankfurt am Maine: Vittorio Klostermann.

Heraclitus. 1979. The Art and Thought of Heraclitus (trans: Kahn, C. E.). Cambridge: Cambridge University Press.

Hill, Annette. 2014. Reality TV. London: Routledge.

Inglis, Fred. 2010. A Short History of Celebrity. Princeton, NJ: Princeton University Press.

Johnson, Shontavia Jackson. 2018. Donald Trump, Disruptive Technologies, and Twitter's Role in the 2016 American Presidential Election. Widener Commonwealth Law Review 27(2018): 39.

Jamieson, Kathleen Hall, and Doron Taussig. 2017. Disruption, Demonization, Deliverance, and Norm Destruction: The Rhetorical Signature of Donald. Journal of Trump Political Science Quarterly 132(4): 619-650.

Johnston, David Cay. 2016. The Making of Donald Trump. Brooklyn: Melville House.

Johnston, David Cay. 2018. It's Even Worse Than You Think: What the Trump Administration is Doing to America. New York: Simon \& Schuster.

Kavka, Misha. 2018. Trump, Fernsehen und das neue Camp. Zeitschrift für Medienwissenschaften 10(1): 149-168.

Kranish, Michael, and Marc Fisher. 2016. Trump Revealed: An American Journey of Ambition, Ego, Money, and Power. New York: Scribner. 
Martin, Keir, and Jakob Krause-Jensen. 2017. Trump: Transacting Trickster. Anthrophology Today 33(3): 4-8.

Massing, Michael. 2018. How Martin Luther Paved The Way For Donald Trump. Nation 306(14): 14

Michels, Tony. 2017. Donald Trump and the Triumph of Antiliberalism. Jewish Social Studies 22(3): 186-192.

Murray, Susan, and Laurie Ouellette (eds.). 2004. Reality TV: Remaking television culture, 2004. New York: NYU Press.

Nakhimovsky, Isaac. 2011. The Closed Commercial State: Perpetual Peace and Commercial Society from Rousseau to Fichte. Princeton NJ: Princeton University Press.

Ouellette, Laurie. 2016. The Trump Show. Television \& New Media 17(7): 647-650.

Papalia, Gerardo. 2017. Trump: Just a Berluscloni. PORTAL Journal of Multidisciplinary International Studies 14: 1. https://epress.lib.uts.edu.au/journals/index.php/portal/article/view/5366. Accessed 17 April 2020.

Rojek, Chris. 2004. Celebrity. London: Reaktion Books.

Siegel, Neil. 2017. Political Norms, Constitutional Conventions, and President Donald Trump. Indiana Law Journal 93: 177-205.

Trump, Donald J., and Tony Schwartz. 1987. The Art of the Deal. New York: Random House.

Tyler, Colin. 2015. Individuality, Freedom and Socialism: The British Idealists' Critiques of the Fichtean State. Political Studies 63(2): 319-335.

Wells, Chris, et al. 2016. How Trump Drove Coverage to the Nomination: Hybrid Media Campaigning. Political Communication 33(4): 669-676.

Werber, Niels. 2017. Trumps Twittern. POP 6(2): 39-44.

Wolff, Michael. 2018. Fire and Fury: Inside the Trump White House. New York: Holt.

Anthony Curtis Adler is Professor of German and Comparative Literature at Yonsei University's Underwood International College, where he has taught since 2006. He has published articles on a range of topics in literary studies, media studies, and philosophy and is also the author of Celebricities: Media Culture and the Phenomenology of Gadget Commodity Life (Fordham 2016). 